\title{
Israel and Palestine, a brief history of the negotiations
}

This article will present a brief history of the negotiations between Israel and Arab counterparts since 1948. The article touches the important and difficult issues of the conflict: Jerusalem, territory, refugees and security.

Shaul Arieli er pensjonert israelsk oberst og seniorforskar ved Economic Cooperation Foundation i Tel Aviv. Arieli var ansvarleg for førebuingane av dei offisielle forhandlingane med palestinarane, som leiar av «Administrasjonen for Interimavtalen» i Yitzhak Rabins regjering, og som leiar av «Fredsadministrasjonen» i Ehud Baraks regjering. 
TEXT: Shaul Arieli

EXITING ISRAELI PRIME MINISTER Ehud Olmert recently briefed the Special Envoy of US president Obama, Senator George Mitchell, about the details of the understandings reached in the negotiations with the chair of the PLO and the PA, Mahmoud Abbas, on the central issues of a permanent status agreement between Israel and the Palestinians. If we ignore the considerable skepticism within the Israeli public about Olmert's motivation and about Abbas' ability to implement the agreement, as well as the continuing decline in Abbas' internal Palestinian legitimacy to lead and represent the Palestinian people, we may point at the formation of the possible breadth of understanding between the moderate camps in the Israeli and Palestinian societies. These concern the core issues of the conflict: territory, Jerusalem, refugees and security. This breadth of understanding is the outcome of a prolonged historical and political process that includes the activities of many stakeholders, both formal and informal, who have had valuable parts in its attainment.

In order to recognize and understand the long path taken by both sides individually and in the framework of the Arab-Israeli-conflict, and in order to point at what is still required from them, and to a no lesser extent from the international community that supports the solution of two states for two people, we should go back to the beginning of the previous century. At that time, a clash took place between two national claims: the right of the Jewish people to self determination in its historic homeland, and the right of the native Arab majority in Palestine to political independence, after it was politically and physically separated from the rest of the Arab people at the end of World War I.

Due to scope constraints and practicality aspirations, however, I seek to concentrate on the development of the parties' positions with regard to the three practical "legacies" left by the ' 48 war. These include borders, Jerusalem and refugees. Their solutions dictates the solution of the fundamental issues: recognition of the right of each side for an independent state of its own, which exists in secure and recognized borders, and in which each side can maintain national identity and character and a democratic regime.

The development of positions was a function of pressures and transformations in each side's internal arena, the Arab and regional arena and the international arena. The conciliation convention held in Lausanne, Switzerland in I949 ended as a 
complete failure. However, it was instructive on the important following details:

First, despite the fact that they engaged in bi-lateral negotiation with Israel on ceasefire agreements signed in I949, the Arab states refused to engage in direct negotiations with Israel on permanent status since it was more convenient for them to present a unified position, in line with the resolution of the Arab League, not to recognize the outcome of the I948 war. Israel understood from this that the Arab states would only talk with Israel if they felt that Israel was capable of threatening the particular interests of each state in theory, or in the event that it threatened them in practice. Therefore, Israel's priority became direct negotiation with each state individually, enabling it to sidestep the commitment to pan-Arab narratives and interests, both real and imagined.

Second, in addition to demanding that Israel accept the same partition boundaries that they had rejected by voting against the UN resolution I8I in I948, the Arab states added far-reaching demands changing those boundaries in their favor, and not in favor of establishing a Palestinian state. ${ }^{\mathrm{I}}$ This move reinforced the Israeli understanding that as far as the Arab world is concerned, it is not about the right of the Palestinian people for an independent state but a territorial dispute that may be resolved by partitioning the territory of the Arab state proposed in UN resolution I8I between Israel and the Arab States.

Third, to Israel, the state's willingness to allow the return of Ioo, ooo Palestinian refugees, to which the Arab response was that it is not enough, reflected the real argument about who is responsible for the refugee problem, Israel or the Arab States. This touched a deeper layer in Israel: assuming that the national and cultural character of democratic states is dictated by the majority, what would be the character of the Israeli state should all refugees return to it? The Israeli position was that an Arab majority would contradict UN resolution I8I determining that Israel will be established as a "Jewish state", and the UNESCO report that determined that "both the Balfour Declaration and the mandate included international commitments to the Jewish people in its entirety". ${ }^{2}$ Fourth, even West Jerusalem, which according to the partition resolution was supposed to be part of the "special regime" of Jerusalem, and under international control, remained in Israeli control. Jerusalem

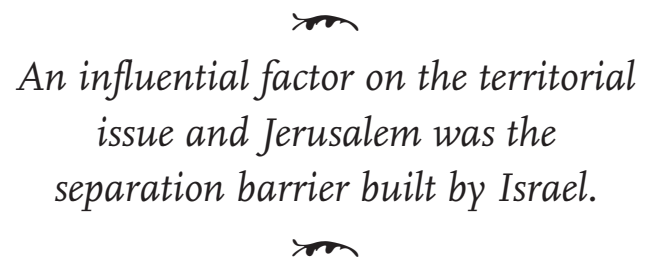

was announced as the Israeli capital and the Knesset as well as the government was relocated there. This happened despite the I949 General Assembly resolution to consider Jerusalem a separate, UN governed entity, ${ }^{3}$ Israel has learned the lesson about the importance of pre-emptive initiative and resolve vis-à-vis positions of the UN, which bore some debt to Israel owing to its failure to implement the partition resolution and prevent the ' 48 war.

Israel's withdrawal from Sinai at the end of the ' 56 war and return to the ' 49 borders demonstrated the capacity of the great powers, US and USSR, to force their will on 
Israel, but undoubtedly also strengthened Israel's hold in territories occupied in the I949 war. Until I967, the Zionist movement proved that it can materialize all of its basic aims within the ' 49 borders, and be satisfied with that, if it had the recognition of and peace agreements with its neighbors.

\section{After the 1967 War}

The UN and USA, whose pre-war guarantees for Israeli freedom of navigation and demilitarization of Sinai proved to be a "signature on ice", ${ }^{4}$ accepted the ' 49 borders at least by implication only in UN Security Council resolution 242 at the end of the ' 67 war. Despite the fact that the resolution begins with "Emphasizing the inadmissibility of the acquisition of territory by war", it continues by determining that Israel shall have just and lasting peace following "withdrawal of Israel armed forces from territories occupied in the recent conflict [only S.A.]". This was the birth of the formula of "land for peace" that subsequently formed the basis of negotiations for the resolution of the Israeli-Arab conflict. Further, the resolution stipulated that the refugee problem should be settled by a just settlement and did not reiterate UN General Assembly resolution I94, which was adopted before the end of the war in December I948.

The three NOs of the September ' 67 Arab League convention in Khartoum, ${ }^{5}$ and the refusal of the newly established PLO to any resolution other than "a single Palestine" on the one hand, and the Israeli power intoxication that led territorial aspirations and the settlement urge on the other, strengthened the Israeli approach on the need to hold on to territories, but also the Israeli settlement project. What appeared to have begun as the old Israeli equation of settlement equals security equals borders, of attempts to annex regions necessary for security, was soon to be transformed. Under the new approach, the "historic right" of the people of Israel outweighed any other consideration or right. Accordingly, the Israeli control of the West Bank and Gaza Strip was deemed legitimate in the eyes of the mainstream Israeli public, as would have been attempts to annex them. Israel sought to occupy the land as it did after the " 48 war, ignoring the differences in circumstances and conditions and with an illusion that this may be done without occupying the Palestinian people who lives there.

The military failure of Syria and Egypt in the ' 73 war did not prevent the latter from starting a political process that ended with a peace agreement with Israel, in which Egypt gained back the Sinai Peninsula. Jordan, which did not participate in the war, rejected in August ' 74 the possibility of interim arrangements with Israel, thus beginning the end of the "Jordanian option". The PLO headed by Yasser Arafat, gained responsibility for the occupied territory in accordance with an October I974 Arab League resolution in Rabat, Morocco. PLO was defined as the "only legitimate representative of the Palestinian people". ${ }^{6}$ This strengthening enabled the PLO to adopt the "phases plan" that included the seeds of a compromise with Israel. Nonetheless, Israel perceived it as a tactical, rather than strategic change in the explicit aim of the organization seeking its destruction.

The peace agreement between Israel and Egypt signed in March 1979 determined 
two constants regarding the territorial issue: the applicable interpretation of resolution 242's territorial article strengthened the Arab position and interpretation, i.e. "the territories in exchange for peace" (according to the French version of the resolution) and that the Gaza Strip is the business of Palestinians vis-à-vis Israel. The thwarting by Likud Prime Minister of the "London Agreement" formulated between Shimon Peres and King Hussein in April I987 led Jordan to exit the territorial game one year later, in July I988. King Hussein declared the disengagement of the Kingdom of Jordan from the West Bank, and a final transmission of all responsibilities and authority to the PLO. ${ }^{8}$

\section{Changes in the PLO}

In the late I980s, following two decades of Yasser Arafat's leadership, the PLO was caught between contradicting trends. Eventually, the newly created world hegemony led to the success of the Reagan administration's pressure on the PLO to change its positions. On November I5 I988, the Palestinian National Council accepted UN resolution I8I that implies the right of Israel to exist and adoption of the two state solution. In December that year Arafat accepted the US conditions for talks with the PLO, including Security Council resolutions 242 and 338 . From there, the road was short to mutual recognition with Israel in the framework of exchange of letters with Prime Minister Rabin in August I993, on the eve of signing the "Declaration of Principles" (the "Oslo Agreement") on September I3, I993 in Washington, D.C.

The Oslo process encountered many ups and downs owing to many factors, notably including: progress was determined to be gradual, conditioned by fragile reality that was threatened by radicals on both sides; divergent interpretation of agreement provisions by the parties; Arafat's failed war against the terrorism of Hamas and the Islamic Jihad that aimed to forestall the political process; Israeli acceleration of the settlement project in the territories; the existence of the Syrian track that competed for Israeli attention and capacity; inadequate management of the negotiations on behalf of both sides; and inadequate US mediation. I will briefly discuss the central "milestones" of the Oslo process in the years I993-200I, with regard to the core issues.

\section{The Oslo Process. Territory}

The territorial issue was central from the beginning and in all interim agreements that were signed. Its non-resolution was a key factor in the failure of the parties to reach a permanent status agreement. Despite the fact that the Oslo agreements signed by Israel included the provision that "the permanent status will lead to the implementation of Security Council Resolutions 242 and 338", 9 Israel did not consider the territorial principle of "all the territories for peace", as implemented in the peace agreements with Egypt and Jordan, as valid for the arrangement with the Palestinians. Prime Minister Rabin was the first to delineate Israel's position in clear geographical terms in his speech at the Knesset in October I995. A transcription of his words into geographical terms would have meant that the Palestinian state, termed by him "the Palestinian entity", would have no more than $75 \%$ of the territory of the West Bank and the Gaza Strip. ${ }^{\circ}$ 
Benjamin Netanyahu who was elected as Prime Minister in I996 was forced to maneuver between his position that "the PLO state that would be planted I5 kilometer from Tel Aviv will constitute an existential threat to the Jewish state", ${ }^{\text {II }}$ and his commitment to agreements signed by Israel and international pressure led by the US to comply with them. Netanyahu succeeded in passing a government decision in I998 on "the map of vital interests" for Israel, which reduced the possible territory for the Palestinian state to only $40 \%$. Ehud Barak, who entered the office of Prime Minister in May I999, began by defining that a solution to the territorial issue will be found by a "just partition of the territories of Judea and Samaria". ${ }^{\text {.2 }}$ The practical interpretation to this position led, in the beginning of the negotiations on a permanent status agreement, to a Palestinian state on $66 \%$ of the territory, which expanded to almost $80 \%$ in the eve of the July 2000 Camp David summit. The Palestinians thoroughly rejected the Israeli position and presented their own formula that matches resolution 242: "I00\% of the territory, minus critical needs of Israel with exchange of territory". ${ }^{\text {r3 }}$ A month before the Camp David summit Israel adopted the first part of that formula, i.e. the ' 67 borders as a base of reference to the issue of borders. This formed, for the first time, a shared basis for negotiations that remained valid to this day.

Exchange of territory represented flexibility on behalf of Palestinians in relation to the basic Arab position of Israeli withdrawal to the ' 67 lines and dismantling of all settlements. Arafat knew that no Israeli government was able to completely evacuate hundreds of thousands of settlers residing in the West Bank. The exchange of territory with a ratio of I:I maintained the Palestinian interest relying on resolution 242 on the one hand, but eased the job for Israeli governments to market the agreement to the Israeli public, as it would be reached at the price of removing only a small fraction of settlers.

The failed 2000 Camp David Summit led to flexibility in the Israeli position, which fluctuated between $87-92 \%$ to the Palestinian state, but was far removed from the Palestinian position that ranged around

Each side will need to demonstrate an effective ability to safeguard the interest of the other side.

leaving only $2 \%$ under Israeli sovereignty and insisted on a I:I exchange ratio rather than the Israeli demand of I:9, as was presented at the Camp David summit. The Taba meeting held in January 200I, after the parties accepted in principle President Clinton's principles published in December 2000, further reduced the gap. Israel came down to $6-8 \%$ while the Palestinians accepted $3-3 \cdot 5 \%$.

The parties turned to engage with the issue of Jerusalem in details only in the framework of the permanent status arrangement, as determined in the "Declaration of Principles". Israel sought to remove the link between "unified Jerusalem" and the larger territorial issue, while the Palestinians insisted on the framework of resolution 242 . Like the other core issues and despite the religious dimension surrounding it, Jerusalem was part of the 
"package deal" intended to bridge the gaps and conclude the entire "give and take" on all of the issues. Subject to the flexibility demonstrated by the Palestinians in their positions on refugees and security, the solution that appeared to be shaped towards the end of the Oslo process was partition of neighborhoods in east Jerusalem according to a demographic principle, including in the Old City, i.e. Jewish neighborhoods under Israeli sovereignty and Arab ones under Palestinian sovereignty. Partition of the sovereignty in the Temple Mount and the Wailing Wall would be done according to the current administrative status quo.

On the issue of Palestinian refugees, the Palestinians were required to accept the most significant compromise since letting go of claims to $78 \%$ of what they considered Palestine (Israel within the ' 67 lines) in I988. The formulation that began prior to the Camp David Summit created a practical solution that concentrated on solving the non-citizenship of Palestinians by means other than returning to Israel, and included compensation through an international mechanism. Disagreements on the narrative of refugee-hood and responsibility for the problem were not completely settled, but were not too far from it.

Israel's unilateral withdrawal from Lebanon in 2000 led to strengthening of the ' 49 borders, as the UN recognized the withdrawal as complying with resolution 425 . However, it also painted a picture according to which Israel withdrew, for the first time, due to military pressure applied by Hizbullah. This had significant influence on Palestinians. Many had regained the feeling that territories could be returned from Israel without paying a political price.
In other words, Arafat's choice of the political process instead of the "armed struggle" was too large and too early a compromise for a Palestinian state on $22 \%$ of the Palestinian homeland, which in fact seemed unattainable from Israel. Despite the fact that this move had strengthened the Hamas movement that denounces any compromise, Israel repeated in summer 2005, under the leadership of Sharon, a unilateral withdrawal from the Gaza Strip which assisted the Hamas election victory in 2006 .

\section{After 200I}

The six years between 200I, when the negotiation for a permanent status agreement stopped, and 2007 when it was renewed in the framework of the Annapolis Summit in the US, were characterized by a range of local dramatic events: the second Intifadah that broke out in October 2000, Sharon's rise to power in February 200I, the death of Arafat and the rise of Mahmoud Abbas in 2004, the Israeli withdrawal from the Gaza Strip and the removal of all Israeli settlements there in the summer of 2005 , Hamas' victory in the Palestinian parliamentary election in 2006 and its military takeover of Gaza in 2007 , the election of Olmert in 2006, and the second Lebanon war in the summer of 2006. During these years, the number of Israelis residing behind the Green Line rose and today reaches almost half a million: I94.000 in the I4 Jewish settlements in east Jerusalem and 290.000 in I30 settlements and dozens of outposts in the West Bank.

Despite the fact that during these years

Israeli soldiers raises the flag in Eilat, I948. 


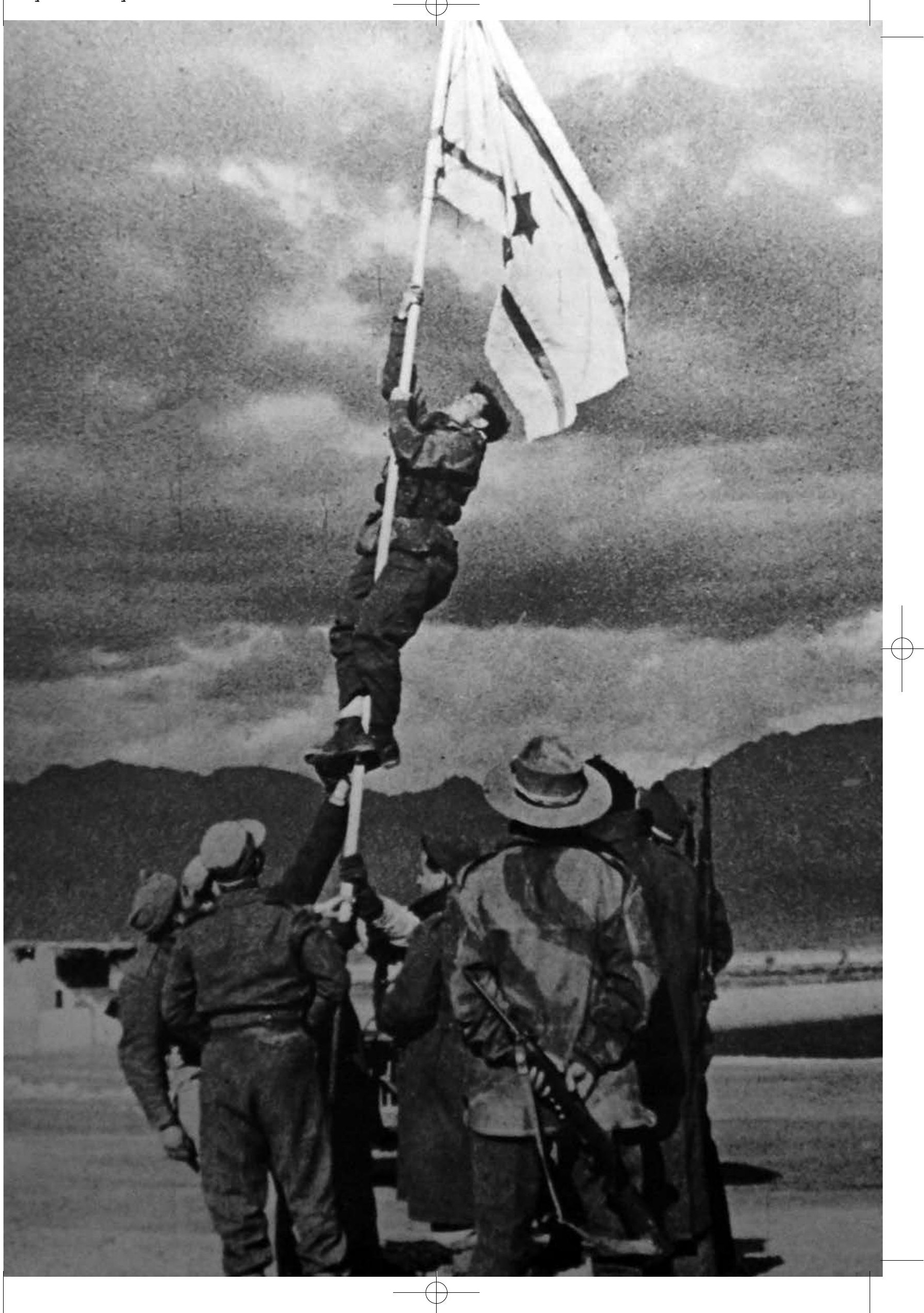


we witnessed a long series of plans such as the Quartet's Road Map (2002), it was mainly the informal initiatives that led to reducing the gaps between the parties: the "Ayalon-Nusseiba" initiative launched in 2003 posing principles for a permanent status agreement, ${ }^{\mathrm{I}}$ and mainly the "Geneva Accords" launched in December 2003. ${ }^{15}$

\section{Separation}

An influential factor on the territorial issue and Jerusalem was the separation barrier built by Israel. From the Israeli side, the barrier was built to answer a security need, facing the wave of terrorism that flooded Israel between 200I and 2003. Its very establishment strengthened the idea of separation, and its route expressed precisely the Israeli position on the issue of borders. ${ }^{16}$ The International Court in The Hague debated the legality of the barrier built by Israel in the territories and published its advisory opinion in July 2004, in which it determined that the route of the barrier and its accompanying regime violate international law. But it also granted Israel, for the first time, conclusive international recognition of the ' 67 lines as its recognized borders.

\section{Annapolis}

The negotiations that took place last year between Israel and the PLO at various levels of government reached the following understandings and gaps. Where the picture is not sufficiently clear, I have chosen to complete it by presenting understandings that took place between the parties in unofficial tracks. On the territorial issue, Israel continues to insist on the planned route of the barrier which would annex $8 \%$ of the territory of the West Bank (not including Arab East Jerusalem), which brings its position to 6.8\%. Despite Abbas' declaration on the eve of the Annapolis Summit of November 2007, that he will only accept $2 \%$ of territorial exchange, he demonstrated greater flexibility in the negotiations and neared 3\% in the overall package deal. An additional contention is the status of the "no-man's land" in the Latrun enclave (located half way between Jerusalem and Tel Aviv) - a territory of 46 square $\mathrm{km}$ ( $0.8 \%$ of the West Bank). Israel claims that it was the first to apply effective control over this no-man land and therefore has sovereignty over it, according to customary law. ${ }^{17}$

Conversely, the Palestinians claim that the area was occupied by Israel in the ' 67 war, and is therefore part of the occupied territories. In my assessment, this contention will not be a hurdle to a resolution on the border, and its solution would similar to the one offered by the Geneva Accords, i.e. equal partition between the parties. This way, even if the entire area stays under Israeli sovereignty, Palestinians will be compensated by exchange of territory.

A stronger contention prevails over the ratio of exchange. Israel proposes 5.5\% around the Gaza Strip and south of the West Bank, and seeks to complete the remainder via a territorial corridor connecting Gaza to the West Bank, though its area is negligible (only 4 square $\mathrm{Km}$ ). This is justified by Israel by the fact that such a connection did not exist prior to the June ' 67 war. The Palestinians insist on a I:I exchange ratio and consider the corridor to be Israeli compensation for the flexibility they demonstrated on other issues, including Israeli use of some of the main roads of 
the Palestinian state via a special arrangement.

On the issue of Jerusalem, the solution rests on two components. The first is partition according to a demographic basis of the Jewish and Arab neighborhoods in east Jerusalem. The second component is the application of a special and international regime, with the participation of Israel and Palestine, on the "historic basin" that includes most of the holy and historic places in Jerusalem, and stretches on 0.25 Hectares. The administration of the holy places will remain unchanged and in accordance with the status quo.

The issue of the refugees rests mostly on the solution suggested initially in Camp David in 2000 and later agreed unofficially in the Geneva Initiative. ${ }^{18}$ However, unlike exiting Prime Minister Ehud Olmert, Foreign Minister and head of the Kadima party Tzipi Livni objects to any return of refugees to Israel, even a symbolic number.

\section{Security}

The issue of security, which has been used in claims made by Israel since its inception, is relatively easier to agree on. Under the rationale that a permanent arrangement should be avoided if it creates a reality of a greater threat potential in the event of non-compliance, Israel seeks to guarantee two interests. The first is that the Palestinian state should not create a more convenient platform from which any coalition of forces from the East might attack Israel. The second is to prevent terrorism against Israel coming from or through the Palestinian state. During the negotiations, Israel internalized the Palestinian basic claim that it is impossible to sign a permanent status agreement that aims to create a better security reality on the one hand, and on the other to maintain military deployment that suits a reality of conflict and violence and preserves the occupation. Israel was thus requested to forgo most of its territorial claims in the

\section{Until 1967, the Zionist movement proved it can materialize all of its basic aims within the ' 49 borders.}

Jordan Valley, which in practical terms and certainly in the public's perception, had served as Israel's defense space against any Eastern threat. Furthermore, Israel has been requested to forgo control of territories east to the Green Line which are strategically situated overlooking Israel's coastal area, including $73 \%$ of its population, as well as civilian and military airports. Thus, the border delineation proposed by Israel is not characterized by consistency with a security rationale, but mainly a demographic and political consideration that seeks to ensure the annexation of a maximum number of Israelis and no Palestinians to Israel. Conversely, over the years the Palestinians have hardened their position that they require a force to protect them from future Israeli invasion. The reoccupation of areas A and B by Israel in 2002 was a response to a wave of terrorism that led to hundreds of casualties and thousands of wounded in the Israeli side. The Palestinians perceive this as an unbearably light application of force and violation of agreements by Israel. ${ }^{19}$

The arrangements required to answer Israeli and Palestinian needs includes 
several main components, according to understandings reached at Camp David and in the Geneva Accord. The first is demilitarization of the Palestinian state, including no Palestinian military and a prohibition on inviting or hosting a foreign military in its territory. Similarly, Palestine will be demilitarized of heavy weapon such as airplanes, tanks, artillery and rocket based weapon, and only agreed upon weapons will be permitted. The aerial space will serve the Israeli air force as well as Palestinian civilian aviation. Second, the Palestinians will establish a strong police force capable of enforcing law and order and fight terrorism. Third, Israel will keep and manage two early warning sites. Fourth, international forces will be deployed in sensitive areas to both sides: on the IsraeliPalestinian border, on the borders between Palestine and Jordan and Egypt, in international passages, in Jerusalem, in early warning sites and along agreed upon routes. Coordination and liaison will apply between all sides.

Finally, one of the central hurdles to attaining an agreement is the question of its implementation, on the backdrop of Hamas' control in Gaza and its refusal to recognize Israel. I do not wish to address the issue of the internal Palestinian conflict in this article, but I would like to overcome this obstacle through a practical separation between the signing of an agreement and its implementation. An agreement will need to pass the required authorizations on both sides, as well as parliamentary voting and/or a referendum. Each side will need to demonstrate an effective ability to safeguard the interest of the other side, prior to moves that entail potential threats. For example, Israel will not pass the control of border passages to Jordan to the Palestinian state prior to the establishment of an international and Palestinian mechanism that can guarantee with reasonable transparency the prevention of smuggling attempts of unauthorized weapons to the Palestinian state. Also, Israel will not transfer to the Palestinians areas adjacent to the Gaza Strip in the context of territorial exchange before the Palestinians clearly materialize in Gaza the principle of "one authority, one weapon". On the other hand, the Palestinians will not accept dismantling of the UNRWA and the cancellation of refugee status before the establishment of an international mechanism responsible for the issues of repatriation and compensation.

In sum, as stated in the beginning of the article, the parties have been through a long and complex path. Along this path, regional and global actors have had a strong influence on the development of their positions. This article has not dealt sufficiently with regional contexts and nearly entirely sidestepped global ones. The chance of reaching a permanent status agreement, and even more importantly to implement it, is conditioned by a series of processes and influencing factors not analyzed here. These include the survivability of the 2002 Arab League peace initiative that strives to end the Arab-Israeli conflict subject to given conditions and compromises, and that includes peace agreements between Israel and Syria, Lebanon and the Palestinians en route to normalization of relations between Israel and the Arab world. They also include regional, national, social and religious confrontations and tensions involving Sunnis and Shiites, fundamentalists and moderates, pro west- 
erners and radicals, hub and periphery in the Middle East and more. They further include Iran's nuclear program and the counter response to it, the future of Iraq and the US involvement there and in Afghanistan.

A permanent agreement between Israel and the Palestinians necessitates deep, intensive and sincere involvement of countries that support it. It requires massive use of "carrots" with both sides, but also of "sticks" when needs be. Without fear of using clichés, the attainment of such an agreement will neutralize one of the most sensitive detonators that may ignite local and regional eruptions whose repercussions may reach everywhere and every field in the world arena. When such an agreement is reached, it will not be a moment too soon.

\section{$\cdot f \cdot$}

I Shlaim, Avi, «The Iron Wall», pp. 74-74, Book in the Attic, 2005 .

2 United Nations Special Committee on Palestine; Report to the General Assembly; Official Records of the Second Session of the General Assembly' New York, I947' ch.2. Article I46.

3 UN General Assembly Resolution I94, IIth December I948, Article 8 .

4 Shlaim, Avi, p.89. On May I7th the President of Egypt demanded from the commander of the UN emergency force in Sinai and the Gaza Strip to withdraw his forces from the border and to redeploy to their base camps. The UN forces waited for the order from the UN Secretary General, and Nasser requested that Secretary General U Thant order the withdrawal of the UN emergency force from Egyptian territory. On May 22nd Nasser's request was granted, and Nasser announced that the following day he would close of the Straights of Teheran to Israeli sea vessels, and that he was willing to go to war with Israel. On May 23rd, the Straights of Teheran were closed to Israeli sea vessels. This was a call to war.

5 The Khartoum Conference was held on Ist September I967 following the Six Day War, and was attended by the leaders of 8 Arab countries. The declaration that was made at the end of the conference defined the Arab policy towards the State of Israel until the Yom Kippur war of I973. This declaration included the "three Nos": No to peace with Israel; No to recognition of Israel, and no to negotiation with Israel.

6 At the Rabat Conference in October I974, leaders of Arab states officially recognized the PLO as the only legitimate representative of the Palestinian people. UN General Assembly resolution 32 Io of the same month also recognized the PLO as such, and UN General Assembly resolution 3237 of November 1974 accorded the PLO observer status at the Assembly.

7 The PLO's "Phased Plan" was the nickname for a plan which was decided upon at the rath Palestinian National Congress which took place in June I974. Article 2 of the plan states, "The Palestinian Liberation Organization will employ all means, and first and foremost armed struggle, to liberate Palestinian territory and to establish the independent combatant national authority for the people over every part of Palestinian territory that is liberated. This will require further changes being effected in the balance of power in favor of our people and their struggle."

8 On 3ist July I988 King Hussein of Jordan announced that the Kingdom would break its legal and administrative ties with the West Bank. On 7th August, King Hussein said at a press conference that Jordan would never again negotiate on behalf of the Palestinians.

9 Declaration of Principles on Interim Self-Government Arrangements (DoP) with the PLO; Washington, September I3th I993.

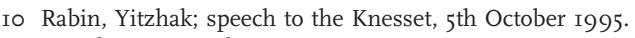
www.knesset.gov.il

II Netanyahu, Binyamin; "Place Under the Sun", Yedioth Ahronoth, I995.

I2 Author's archive.

I3 Drafts presented during negotiations in 2000 .

I4 See website http://www.mifkad.org.il/

I5 See website http://www.mifkad.org.il/

I6 Arieli, Shaul, Sfard Michael; "The Wall of Folly” (Hebrew), Book in the Attic, 2008.

I7 State of Israel v. Eitan Kramer, 3/3/2004, (criminal)ıI93/04.

I8 See website http://www.heskem.org.il/; Article 7 of the Agreement.

I9 Conversations between the author and Palestinian counterparts. 